\title{
The Learning Model of Forearm Passing In Volleyball for Junior High School
}

\author{
Titi Ajayati \\ State University of Jakarta, Jakarta, Indonesia \\ E-mail:Tajayati@gmail.com
}

\begin{abstract}
The purpose of this research and development is to produce the learning models of volleyball forearm for junior high school age. In addition, research and development are conducted to Obtain in-depth information about the development and application of the learning models of volleyball forearm for junior high school age and Determine the effectiveness, efficiency, and attractiveness of the models created a child. This research uses methods development research \& development (R \& D) from Borg and Gall. Subjects in research and development are the students of junior high school consisting of 35 children. The Instruments that used in this research and development is a questionnaire, as well as the instrument volleyball passing a test that used to collect data of the forearm passing in volleyball for junior high school age. As for the stages in research and development are (1) analysis of needs, (2) the expert evaluation (initial product evaluation); (3) limited trial (small group testing); and (4) the main trial (field testing). The effectiveness model of test used forearm passing to know the level of forearm passing ability for junior high school age before giving treatment such as forearm passing models that developed and to Determine the forearm passing ability after treatment or forearm passing treatment that developed, from the initial tests were conducted obtained the student forearm passing levels are 21.06, then after being given treatment in the form of forearm passing model. The students' forearm passing skils obtained the ability levels are 26.26. Accordingly, this volleyball forearm passing model is effective to raise the learning models of forearm passing in volleyball for junior high school age. Based on the results of the development can be concluded that: (1) the forearm passing in volleyball learning models for junior high school age can be developed and applied in physical education learning at schools (2) the forearm passing in volleyball learning models for junior high school age the which have been developed, acquired improvement evidence of this is shown in the result of testing the data from the pretest and posttest there is significant difference between before and after the development of a models.
\end{abstract}

Keywords: Development, Model, Underpassing

\section{INTRODUCTION}

Volleyball is one sport which includes compulsory subject in physical education lesson that should be taught in schools. The involvement of students in learning volleyball program is expected to help optimize the growth and development of students, improve students' physical fitness components, such as endurance strength, power, flexibility, agility, balance and motor coordination. In addition to developing the physical aspects of learning, volleyball are also expected to develop the mental aspects such as motivation to learn, confidence, courage, and discipline, tolerance and cooperation is the social aspect is also expected to experience a change for the better.

Muhajir (2007) The game of volleyball is a sport which volley shaped ball in the air back and forth at the top of the net/net with the intention to drop the ball in the opposite field plots to seek victory. In the game of volleyball can be in use part of the body and volleyball games can be played by two teams, each team consists of six players.

Education is an effort to develop one's personality in one of his favorite destinations. In the development of personality in education seen in the realization of individual potential and it can be taken as a provision for the future. To achieve the goals of individuals in achieving the required education learning innovation which is always increasing. As well as improving the quality of physical education. Husdarta (2011) states that "physical education and health is essentially a process of education that utilizes physical activity and health to produce a holistic change in the quality of the individual, both in terms of physical, mental, and emotional".

Physical education certainly has the educational goals to be achieved. In achieving the goal of education it is necessary to the learning process that is a series of reciprocal activity between teachers and students, it is necessary for the series of planned learning activities. With a planned education and guidance both educational goals will be achieved with good as well. Kemenegpora (2011), In Law No. 3 2005, article 1, paragraph 11 of the National Sports System is formulated that "education is a sport physical education and sport undertaken as part of the process of 
regular and ongoing education to acquire knowledge, personality, skills, health and physical fitness".

Programming can be done to improve learning outcomes in the subjects of physical education are so many ways and methods, both in terms of infrastructure innovation learning, methods of teaching, the approach in the learning process, and so on.In the learning process is expected physical education teacher is able to provide science and overall knowledge. In the learning process of a teacher of physical education course must pay attention to the age characteristics of each level of education, because the physical education instructional design skills refer to the ability according to the theory phases of child development. Simply put, motor learning can be defined as the process of learning skills smoothing movement and motor skills, as well as the variables that support or hinder finesse and kehalian motor. According to Ricard Decaprio (2013), Aspects of motor learning in education is "Aspects related to the actions or behavior displayed by the students after receiving certain material from a teacher".

Based on the above opinion can be concluded that the purpose of the participation of students in volleyball is to improve basic motor skills, improve physical fitness components, develop motor skills, introduced the skills of forearm passing in volleyball and help improve student's confidence.

Goals to be achieved through learning programs volleyball in different schools with the goal of club volleyball achievement. Learning volleyball schools put more emphasis on achieving full three aspects, namely cognitive, affective and psychomotor. Jim Lavin (2008), states "Every child is capable of being creative. However, when pupils are forced to suppress Reviews their creativity by participating in an activity they dislike or roommates do not motivate them, then Reviews their response can lead to Inappropriate behavior ". The statement explains that every child has the ability developing creativity, but when children are forced to emphasize their creativity by participating in an activity that does not like or that do not motivate them, it is difficult to appear. The weakness in physical education often monotonous development models often make students experiencing saturation in participating physical education.

So expect the use of these models, the teacher can harmonize with the conditions and situations faced by students. Making the right development model in the material passing under the course movements must support related to forearm passing in volleyball (starters and continued movement). Terkait with statements that have been mentioned above, it shows that the need to develop models of forearm passing in volleyball, which can later be used as a solution to help students learn passing more effectively below.

Based on observations and interviews the author with a physical education teacher found the facts as follows: The learning process of forearm passing in volleyball in junior high school running smoothly, but not all of the material that is mandated curriculum can be implemented, the method taught in teaching is still conventional, learning objectives adequacy indicator has not been achieved with unmet student movement, and motor skills the student has not included good category, facilities, and infrastructure for learning volleyball is still lacking, learning programs volleyball applied to activity still refers volleyball program achievement.

To overcome the problems in learning to pass under volleyball as has been described above, the research and development of instructional model of forearm passing in volleyball for secondary school students are important.

Concept of Research and Development

Research and development by Borg \& Gall (1983) is a process used to develop and validate the educational product. According to Nusa (2011), research and development is a term used to describe the activities associated with the creation or invention, methods, and new products or services by using the new knowledge that is found to meet the needs of the market or demands.

Research and development by Sugiyono stated that the research and development of the research methods used to produce a specific product and test the effectiveness of such products (2013) therefore the development of the learning model is the result of research, results-oriented development product. Therefore, research and development to produce products and can be tested the effectiveness of the product. Sukmadinata (2005) explained that the products resulting from research and development activities are not always shaped objects or equipment(hardware), such as books, modules, teaching aids, but can also software(software), such as computer programs, classroom, library or laboratory, or models of education, learning, guidance, evaluation, management, and others

Description Volleyball

Volleyball is one sport that is popular among people of lower ranks to the top. According to Ahmadi (2007) "volleyball is a complex game that is not easily done by everyone because in the game of volleyball necessary motor coordination can really be relied upon to perform all the movements that exist in the game of volleyball. Although so it does not preclude the public to learn more because of interest occurring in high society.

Another advantage of volleyball was expressed also by Papageorgiou stating "Volleyball is a game that is suitable for both Sexes and for players of all ages and abilities and can be adapted to allow players with a physical or mental disability to play at a competitive level". Games that can be played by men and women even for people with special needs course with the adjustable degree of difficulty in competing. Barbara and Bonnie (2010) states other advantages of the game of volleyball, among others:

(1) It is adaptable to various conditions that may present themselves, (2) It can be played with any number on a side from two, the which is extremely popular in the beach game, to six. the which is the 
number used for interscholastic, Intercollegiate, juniors, and club play, (3) It can be played and enjoyed by all ages and ability levels, (4) It can be played on many surfaces-grass, wood, sand, and various artificial surfaces, (5) It is an excellent coed activity, (6) It is an exciting spectator sport, (7) It can be played indoors or outdoors, (8) It is an extremely popular recreational activity with numerous leagues in business, community, and school intramural programs, (9) it requires few basic rules and skills, and (10) it has limited equipment needs.

Based on these statements volleyball games have the advantage that can be played in a variety of conditions, this game can be modified by the number of people (flexible), can be played between schools, colleagues, and also clubs volleyball, but it can be played by all ages and at the level of ability. This game can be done in all forms of the court, sand, grass, cement and so on. Another advantage of this game is an amazing game because through volleyball games can generate interest in the local audience, this game can be played outside and indoors.

\section{RESEARCH METHOD}

The approach used in this study is a qualitative and quantitative approach, which is an approach to finding answers to the problem through the formulation of the problem that has been formulated in the first chapter that is learning to pass under volleyball for junior high school age.

The final results of this development is a learning model of forearm passing in volleyball for secondary school age will produce a product in the form of learning methods complete with product specifications as well as test the effectiveness of the learning model made, so as to increase students' motivation and can also be used as a guidance for teacher to enhance learning passing in volleyball below. Research and development in this study using qualitative and quantitative approach using a model of the development of Research \& Development (R \& D) from Borg and Gall consisting of ten steps or can also be described in terms of stages of development schemes as shown below:

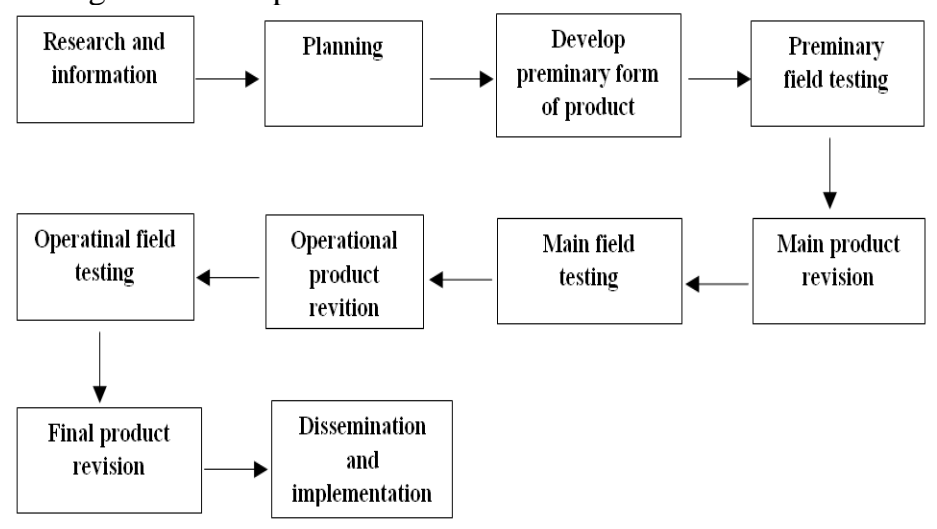

Fig. 1 Instructional Design R \& D

\section{RESULT AND DISCUSSION}

Based on the results of the feasibility study model test of passing conducted on a model under which totaled 23. The results obtained a score of 58 out of a maximum score of 69 or with the average percentage of use of the model by $84.06 \%$ so that the use of this development model, on the whole, can be categorized feasible and suitable for use in the development of the learning forearm passing in volleyball model. Based on data collected from each of experts consisting of three experts there are still some products that need to be revised draft before the small group trial and testing of products intended for the big group. Revision scheme aims to develop a better product. products developed is a summary revision products based on the advice of experts as follows:

1. The Directions of implementation the movement forearm passing in volleyball should be made clearly that easy to be understood by the student.

2. Image of the model must be clear in order to understand the students.

3. The model had to be absolutely safe.

4. The ball that is used must be considered in terms of the quality level of air pressure.

5. Implementation should be clear that the results of the learning of forearm passing will be good.

6. Models of learning forearm passing in volleyball must accentuate the safety of students. The distance between the cone should be noticed and adjusted to the student.

7. Each item in learning model of forearm passing in volleyball should contribute to good forearm passing in order not to deviate from the learning objectives;

Effectiveness Model

Level of effectiveness scheme would learning model developed in this study were obtained from the small group trial, testing a large group and test the effectiveness of the model with providing treatment model of learning obtained by learners. the results of the trial are the basis for researchers to conduct that developed effective learning model used in the learning process of forearm passing in volleyball in junior high school age. Here will be presented the data from each trial.

Results of First Stage / Small GroupTrials

Trials shall group will obtain data about the ease and attractiveness of the teaching model passing under volleyball on the subjects of physical education, sports, and health. The subject trial in the small group trial 24 Kaur junior high school students were 12 learners are taken randomly. Data retrieved by providing a questionnaire instrument questioner. after the data obtained is then calculated the average yield of the number of answers obtained from the questionnaire filling. 
Table I

Results of Data Analysis Trial Small Groups

\begin{tabular}{clcccc}
\hline No & Variable & $\begin{array}{c}\text { Results } \\
\text { Score }\end{array}$ & $\begin{array}{c}\text { Maximum } \\
\text { Score }\end{array}$ & $\%$ & Information \\
\hline 1 & Convenience & $\mathbf{8 5 9}$ & 1104 & 77,81 & Good \\
\hline 2 & Attractiveness & $\mathbf{9 8 2}$ & 1104 & $\mathbf{8 8 , 9 5}$ & Very Good \\
\hline
\end{tabular}

Based on the table above ease of learning models of forearm passing in volleyball values obtained $77.81 \%$ and otherwise well. Based on the attractiveness of the teaching model of forearm passing in volleyball of volleyball values obtained $88.95 \%$ and otherwise well. The results of the data analysis test a small group in the table above to learners junior high school age can be concluded that the learning model of forearm passing in volleyball for junior high school age can continue to test a large group with several records including 1) The use of facilities on the learning model of forearm passing in volleyball the bottom portion should be revised because it feels difficult to do by learners in junior high school age, 2) frequency of motion of each model enhanced learning, 3) the distance between the teams in group learning models adapted to the field.

Results of Second Stage / Trial Large Group

Following will be presented the data processing results of the evaluation test large groups of product development learning models of forearm passing in volleyball on the subjects of Physical Education, Sport, and Health on testing a large group of 60 students from three junior drawn randomly.

Event large group trial conducted on March 20, 2016 (SMP N 6 Kaur), 10 April 2016 (SMP N 2 Kaur), 20 April 2016 (SMP N 3 Kaur). Data collected by giving instrument the form proficiency test technique of forearm passing. Once the data is obtained and then calculated the average results of students' ability to perform forearm passing volleyball both data Preliminary Tests and Final Test.

Table II

The Ability of Forearm Passing in Volleyball

Number

Pre-Test

Post-Test

\begin{tabular}{lll}
\hline 1 & 23 & 30 \\
\hline 2 & 26 & 30 \\
\hline 3 & 17 & 23 \\
\hline 4 & 23 & 30 \\
\hline 5 & 15 & 21 \\
\hline 6 & 23 & 30 \\
\hline 7 & 16 & 20 \\
\hline 8 & 23 & 30 \\
\hline 9 & 17 & 20 \\
\hline 10 & 15 & 19 \\
\hline 11 & 17 & 24 \\
\hline
\end{tabular}

\begin{tabular}{|c|c|c|}
\hline 12 & 23 & 30 \\
\hline 13 & 20 & 26 \\
\hline 14 & 23 & 23 \\
\hline 15 & 20 & 30 \\
\hline 16 & 19 & 28 \\
\hline 17 & 25 & 34 \\
\hline 18 & 23 & 24 \\
\hline 19 & 17 & 20 \\
\hline 20 & 23 & 26 \\
\hline 21 & 22 & 27 \\
\hline 22 & 23 & 28 \\
\hline 23 & 23 & 28 \\
\hline 24 & 27 & 30 \\
\hline 25 & 23 & 23 \\
\hline 26 & 21 & 26 \\
\hline 27 & 23 & 25 \\
\hline 28 & 19 & 30 \\
\hline 29 & 21 & 27 \\
\hline 30 & 20 & 26 \\
\hline 31 & 23 & 23 \\
\hline 32 & 21 & 26 \\
\hline 33 & 23 & 25 \\
\hline 34 & 19 & 30 \\
\hline 35 & 21 & 27 \\
\hline Total & 737 & 919 \\
\hline mean & 21:06 & 26.26 \\
\hline SD & $3: 02$ & 3.70 \\
\hline
\end{tabular}

Based on the analysis of data that the average value of learning outcomes of forearm passing in volleyball before being given by the model of learning is 21.06 and after being given by the treatment with 26,26 means learning model that the average value of forearm passing is increased.

Learning Model Product Effectiveness Test Passing Down

After revised the final product is finished and then the product dieksperimenkan to determine the effectiveness of product development tersebut.uji effectiveness of these products using a design one group pretest-posttest design,namely by performing initial tests and the pretest or posttest or perform final tests for the experimental group. To determine the effectiveness of the learning model development product of forearm passing in volleyball at the age of junior high volleyball test mean difference. 
Table III

Test Difference Effectiveness of Learning Model of Forearm Passing in Volleyball

\begin{tabular}{ccccc}
\hline $\begin{array}{c}\text { Number of } \\
\text { Samples }\end{array}$ & db & $\begin{array}{c}\mathbf{t}- \\
\text { statistics }\end{array}$ & t-table a=0.05 & Decision \\
\hline 35 & 57 & 6,307 & 2,000 & Rejected \\
\hline
\end{tabular}

\section{Description:}

Db:

Degree free

t-test:

price $t$ count

t-table:

Based on the analysis of data obtained $t_{0}$ of 6.307 and $t_{\text {table }}$ 2,000with 3 degrees of freedom and $a=0: 05$. thus, $t_{0}=$ $6.307>t_{\text {table }}=2.000$ or $H_{0}$ is rejected. Because $H_{0}$ is rejected, the $\mathrm{h} 1$ is accepted, there is a difference between the results of forearm passing in volleyball learners after given by the learning model of forearm passing in volleyball at the initial test and final test.

\section{Discussion}

The end result of the learning model development product of forearm passing of volleyball after the study in the form of learning model book of forearm passing of volleyball. The development of learning book of forearm passing volleyball on the subjects of physical education, sports, and health based on the analysis of the needs of schools. the results of the analysis of the needs in the school. the results of the needs analysis showed that:

1. Physical education teacher has taught some techniques in the game of volleyball but learning the techniques of passing under not optimal variations.

2. The material technique of forearm passing is taught to eighth-grade students in junior high school each semester conformed to $\mathrm{KI}$ and $\mathrm{KD}$ in the 2013 curriculum developed by each school.

3. The ingredients used in volleyball teaching is still limited to the net, cone, and volleyball.

4. Teachers still use the lessons volleyball watching just by learning in groups and pairs.

5. Students are enthusiastic about participating in learning techniques passing for down but still less varied learning models so that students get bored just playing in the environment field.

6. Teachers are already making maximum efforts provide material passing down to children more interested in learning the passing down, but because of lack of resources learning model that is causing difficulty in adding reference teacher learning motion of forearm passing will be granted.

7. In general, teachers in desperate need of a wide variety of learning models motion passing under varied mainly by the inclusion of a customized learning model of a simple movement to a complex movement.

After analyzing the needs of the learning model under very important passing researchers made 23 models which are then submitted to 3 experts to the requested

validation of models that have been made by the researcher. Based on the feasibility test results under the passing learning model performed on a model that was 23 contained in the table above, Results obtained score of 58 out of a maximum score of 69 , or to the average percentage yield of $84.06 \%$ usage models so that on the whole the model can be categorized on the development of feasible and suitable used in the development of the learning model of the forearm passing in volleyball.

Based on the test results of small group and large group trial data obtained as follows. From the test results obtained by a small group, results criteria are reviewed aspects of ease of learning model of forearm passing in volleyball values obtained $77.81 \%$ and otherwise well. Meanwhile, from the aspect of the attractiveness of the teaching model of the forearm passing in volleyball values obtained $88.95 \%$ and otherwise well.

The results of the small group trial have a positive value, the researchers went on to large-scale trial involving 35 subjects from three schools in the district Kaur. From the test results obtained by a large group difference in the average count of the initial test and the final test of the forearm passing in volleyball.

Based on the formulation of the problem researchers want to see the effectiveness of a 23 developed model and applied to the students, the results obtained show $\mathrm{t}_{0}$ of 6.307 and $\mathrm{t}_{\text {table }} 2.000 \mathrm{with} 57$ degrees of freedom and $\mathrm{a}=$ 0:05. Thus, $t_{0}=6.307>t_{\text {table }}=2.000$ or $H_{0}$ is rejected. Because $\mathrm{H}_{0}$ is rejected then $\mathrm{H}_{1}$ accepted, so that it can be concluded there is a difference between the results of the forearm passing in volleyball learners after learning the model granted passing volleyball at the initial test and final test.

Learning model of forearm passing of volleyball that was developed researcher has the advantages of:

1. Learning model was developed with a design that is simple to the complex movement.

2. The frequency and intensity of movement of each learning models adapted to the characteristics of learners junior high school age children.

3. Presenting an active learning model, effective and efficient and can be performed by all learners who can already play volleyball basic engineering materials.

4. Learners are more active in the learning process

5. Equipment used is safe for learners and easily obtainable

While the weakness of the learning model of the forearm passing in volleyball developed by the researcher has the disadvantage that:

1. It takes in preparing a learning tool before practice

2. Because of this learning model for the junior high school age students who do not understand the materials of volleyball basic techniques of junior high school age will take a little longer to practice all movements. 


\section{IV.CONCLUSIONS}

In this study model development, the resulting product in the form of learning models passing under volleyball packaged in a guidebook learning. Based on the data collected from the research consists of variable experts, the small group trial and testing of large groups as well as the discussion of research results, the researchers can draw the conclusion that:

1. The results of the needs analysis showed that the learning model of the forearm passing in volleyball highly needed by physical education teachers. Based on 23 learning model development of forearm passing of volleyball researchers, the results of the validation of three experts obtained a score of 58 on the results of a maximum score of 69 or with the average percentage of use of the model by $84.06 \%$ so that the overall use of models at this development can be categorized decent and suitable for use in the development of the learning passing down model.The results of the small group trial criteria obtained results are reviewed aspects of ease of learning model of the forearm passing in volleyball values obtained $77.01 \%$ and otherwise well, while aspects of the attractiveness of the values obtained 88.95\% and otherwise well. Test Results A large group of initial test and final testability of passing under volleyball game there are differences in average is 21.06 average initial test be 26.26 on the final test.

2. The effectiveness of the model developed is effective to use. based on the results of the comparison between the pretest and posttest were given to the students obtained the $\mathrm{t}_{0}$ of 6.307 and $\mathrm{t}_{\text {table }} 2.000$ thus, $\mathrm{t}_{0}=6.307>\mathrm{t}_{\text {table }}=$ 2.000 or $\mathrm{H}_{0}$ is rejected. It can be concluded there is a difference between the results of students' forearm passing in volleyball after given learning model of volleyball passing.

\section{REFERENCES}

Muhajir. Pendidikan Jasmani Olahraga \& Kesehatan, Bandung: Ghalia Indonesia Printing, 2007.

Husdarta. Manajemen Pendidikan Jasmani. Bandung: Alfabeta, 2011.

Kemenegpora. Undang-Undang Republik Indonesia Nomor 3 Tahun 2005Tentang Sistem Keolahragaan Nasional. Jakarta: Kemenegpora, 2011.

R. Decaprio. Aplikasi Teori Pembelajaran Motorik di Sekolah. Jogjakarta: Diva Press, 2013.

J. Lavin.Creative Approaches to Physical Education Helping Children to Achieve Their True Potensial.Canada: Routledge, 2008.

W. R. Borg and M.D. Gall. Educational Research An Introduction. New York: Longman, 1983.

N. Putra. Penelitian Kualitatif: Proses dan Aplikasi. Jakarta: PT Indeks, 2011.

Sugiyono. Metode Penelitian Kuantitatif, Kualitatif dan $R \& D$. Bandung: Alfabeta, 2013.

Sukmadinata.Metode Penelitian Pendidikan, Jakarta: PPs UPI dan PT Remaja Rosdakarya, 2005.

N. Ahmadi. Panduan Olahraga Bola Voli. Surakarta: Era Pustaka Utama, 2007.

B. L Viera and B.J Ferguson.Volleyball Step to Succes Second Edition.Canada:Human Kinetics, 2010. 